\title{
ANALISIS FAKTOR-FAKTOR YANG MEMPENGARUHI TINGKAT PENERIMAAN DAN PENGGUNAAN SIM ONLINE DILINGKUP PELAYANAN POLRESTA DENPASAR MENGGUNAKAN MODEL UNIFIED THEORY OF ACCEPTANCE AND USE OF TECHNOLOGY (UTAUT)
}

\author{
Alfin Nur ${ }^{1}$, I Made Ardwi Pradnyana ${ }^{2}$, Made Windu Antara Kesiman ${ }^{3}$ \\ Prodi Pendidikan Teknik Informatika \\ Jurusan Teknik Informatika \\ Universitas Pendidikan Ganesha \\ Singaraja,Bali \\ Email:alfinnur929@gmail.com ${ }^{1}$, ardwi.pradnyana@undiksha.ac.id², antara.kesiman@undiksha.ac.id ${ }^{3}$
}

\begin{abstract}
Abstrak - SIM Online atau Surat Izin Mengemudi Online adalah layanan untuk mempermudahkan masyarakat dalam melakukan pembuatan atau perpanjangan SIM secara Online.Tujuan dari penelitian ini adalah untuk mengetahui bagaimana penerimaan pengguna terhadap SIM Online sehingga pengembangan sistem layak dilaksanakan. Salah satu pendekatan teori penerimaan dan penggunaan terhadap suatu teknologi yaitu Unified Theory Of Acceptance And Use Of Technology (UTAUT). UTAUT merupakan salah satu model penerimaan teknologi yang dikembangkan oleh Vankates et al. (2003). UTAUT memiliki empat konstruk utama yaitu Ekspektasi Kinerja, Ekspektasi Usaha, Pengaruh Sosial, Kondisi Yang Memfasilitasi. Hasil penelitian menunjukkan bahwa (1) Ekspektasi kinerja,ekpektasi usaha, pengaruh sosial positif terhadap minat pemanfaatan SIM Online (2) Faktor kondisi yang memfasilitasi dan minat pemanfaatan berpengaruh positif terhadap perilaku pengguna (3) Variabel moderator jenis kelamin memperkuat hubungan ekspektasi kinerja, ekspektasi usaha, pengaruh sosial terhadap minat pemanfaatan SIM Online (4) Variabel moderator umur memperlemah hubungan ekspektasi kinerja sedangkan variabel umur memperkuat hubungan ekspektasi usaha, pengaruh sosial, kondisi yang memfasilitasi terhadap minat pemanfaatan SIM Online (5) Variabel moderator pengalaman memperkuat hubungan ekspektasi usaha, pengaruh sosial, kondisi yang memfasilitasi terhadap minat pemanfaatan SIM Online.
\end{abstract}

Kata kunci : SIM Online, Ekspektansi Kinerja, Ekspektansi Usaha, Pengaruh Sosial, Kondisi yang memfasilitasi, Minat Pemanfaatan, Perilaku pengguna, UTAUT.
Abstract - Driving License Online is a social service to facilitate the society to make or extended the use of driving license as online. The aim of this research was to explore how the acceptance of users towards Driving License Online to know that the development of this system was suitable to use. One of the theories used was Unified Theory of Acceptance and Use of Technology (UTAUT). UTAUT is one of technology acceptance model which developed by Vankates et al. (2003). UTAUT has four main construct namely, performance expectation, effort expectation, social influence and facilitated condition. The result showed that (1) performance expectation, effort expectation and social influence gave the positive effect towards the users' interest of Driving License Online (2) facilitated condition and the interest of using Driving License Online gave the positive effect towards the users, behavior (3) variable of gender strengthen the relation of performance expectation, effort expectation and social influence towards the interest of using Driving License Online (4) variable of age weaken the performance expectation but strengthen the connection of effort expectation, social influence and facilitated condition towards the interest of using Driving License Online (5) variable of experience strengthen the relation of performance expectation, social influence and facilitated condition towards the interest of using Driving License Online.

Keywords: Driving License Online, performance expectation, effort expectation, social influence and facilitated condition, interest, behavior of user, UTAUT 


\section{PENDAHULUAN}

Surat Izin Mengemudi ("SIM") adalah tanda bukti legitimasi kompetensi, alat kontrol, dan data forensik kepolisian bagi seseorang yang telah lulus uji pengetahuan, kemampuan, dan keterampilan untuk mengemudikan kendaraan bermotor ("Ranmor") di jalan sesuai dengan persyaratan yang ditentukan berdasarkan Undang-Undang Lalu Lintas dan Angkutan Jalan menurut UU Nomor 22 Tahun 2009 [1]. Dalam mengoptimalkan pelayanan kepada masyarakat, KORLANTAS saat ini memiliki program baru yaitu SIM Online. Melalui SIM Online ini masyarakat dapat membuat dan memperpanjang Sim secara mudah, yakni masyarakat yang dulunya penerbitan Sim dari wilayah kota yang berbeda, sekarang bisa membuat Sim di daerah tempat tinggalnya saat ini, tetapi masyarakat disini dituntut untuk memiliki E-KTP jika masyarakat tidak memiliki E-KTP maka masyarakat tersebut tidak bisa melakukan pembuatan SIM secara Online. SIM Online ini telah berfungsi sebagaimana mestinya dan dapat diakses melalui http://sim.korlantas.polri.go.id/simonline-registrasi/.

Berdasarkan hasil wawancara dengan Regident Satlantas Polres Denpasar, Di Kota Denpasar sendiri pemanfaatan SIM Online melalui Android ini masih belum maksimal. Kenyataannya banyak Sumber Daya Manusia (SDM) yang belum menggunakan SIM Online untuk melakukan proses pembuatan dan perpanjangan SIM. Idealnya penggunaan SIM Online digunakan oleh seluruh masyarakat. Berdasarkan hal tersebut agar mampu mengatasi permasalahan terkait dengan belum digunakannya secara optimal SIM Online agar nantinya mendapatkan manfaat yang sesuai dengan harapan, agar nantinya SIM Online diterima dan digunakan dengan optimal oleh pengguna, sehingga dapat memberikan kontribusi terhadap kemajuan sistem tersebut.Penelitian ini akan dilakukan pengujian penerimaan dan pengunaan terhadap SIM Online, karena penelitian sebelumnya belum terdapat pengujian penerimaan dan penggunaan terhadap SIM Online.

Berdasarkan permasalahan diatas penting dilakukan analisis untuk mengetahui bagaimana penerimaan dan penggunaan terhadap sistem tersebut sehingga sistem tersebut dapat dikatakan layak. Dalam penelitian sistem teknologi informasi, ada beberapa teori yang digunakan salah satunya yaitu UTAUT (Unified Theory of Acceptance and Use of Technology). UTAUT disini mememiliki 4 konstruk utama yang berpengaruh langsung terhadap penerimaan pemakai dan perilaku pemakai. Keempat konstruk itu ekspektasi kinerja (performance expectancy), ekspektasi usaha (effort expectancy), pengaruh sosial (social influence), dan kondisikondisi pemfasilitasi (facilitating conditions) dan memiliki empat variabel sebagai moderator (moderating variables), yaitu jenis kelamin (Gender), usia (Age), pengalaman (Experience), dan kesukarelaan penggunaan (voluntariness of use) (Mustaqim, Kusyanti, and Aryadita 2018)
Berdasarkan pada pemikiran tersebut, maka peneliti disini tertarik untuk mengadakan penelitian tentang "Analisis Faktor-faktor yang mempengaruhi tingkat penerimaan dan penggunaan SIM Online dilingkup pelayanan Polresta Denpasar menggunakan Model Unified Theory Of Acceptance And Use Of Technology (UTAUT)" .Diharapkan nantinya mendapatkan hasil seberapa besar pengaruh konstruk UTAUT terhadap penerimaan SIM Online dikalangan masyarakat.

\section{KAJIAN TEORI}

\section{A. SIM Online}

Surat Ijin Mengemudi (SIM) online merupakan suatu sistem informasi teknologi yang berbasis web dengan mengimplimentasikan layanan pendaftaran SIM baru, perpanjangan secara online, mekanisme penerbitan SIM, materi uji praktik roda 2 dan roda 4 , tarif biaya penerbitan SIM dan peta lokasi atau maps SIM Corner dan SIM keliling. SIM online merupakan konsep aplikasi SIM Polri 2015 yang saat dikembangkan dengan menggunakan konsep "OCI" yaitu Online Centralized dan Integrated. Dasar hukum dari SIM Online adalah Undang-Undang Nomor 2 Tahun 2002 tentang Kepolisian Negara Republik Indonesia, Undang-Undang Nomor 22 Tahun 2009 tentang Lalu lintas dan Angkutan Jalan.(Fatimah 2017). (Moenir 2010) dalam (Triyanti 2016) mengatakan bahwa bentuk pelayanan publik ada tiga, yaitu pelayanan berbentuk lisan, tulisan dan perbuatan. Dalam rangka penyelenggaraan pelayanan publik mulai 1 Juli 2015 Mabes Polri telah melaksanakan program terintegrasi pelayanan perpanjangan masa berlaku SIM secara nasional dengan sistem "online". Program ini diselenggarakan untuk mempermudahkan masyarakat yang tinggal jauh dari tempat asalnya.

\section{B. Unified Theory of Acceptance and Use of Technology (UTAUT)}

UTAUT merupakan sebuah model penerimaan teknologi yang diusulkan oleh Viswanath Venkatesh, dkk pada tahun 2003[2]. Dengan menggabungkan 8 model di dalamnya, Setelah mengevaluasi kedelapan model tersebut, terdapat tujuh konstruk tampaknya selalu signifikan menjadi pengaruhpengaruh langsung terhadap niat (intetion) atau terhadap perilaku (usage). Dari ketujuh konstruk ini adalah perfomance expectancy, effort expectancy, sosial influence, facilitating conditions, attitude toward using technology, self-efficacy dan anxiety. Dari ketujuh konstruk tersebut Vankatesh, et al menganggap ada empat konstruk di anggap mempunyai peran utama dalam pengaruh-pengaruh langsung terhadap penerimaan pemakai dan perilaku pemakai. Keempat konstruk itu adalah perfomance expectancy, effort expectancy, sosial influence, facilitating conditions. Ketiga konstruk lainnya digunakan tetapi tidak digambarkan dalam model yaitu attitude toward using technology, self-efficacy dan anxiety karena diteorikan bukan sebagai pengaruh langusng ke minat 
pemanfaatan(BI) namun tidak menggunakan kesukarelaan penggguna (voluntariness of use) karena konstruk pengaruh sosial tidak akan siginifikan terhadap penggunaan pada kontek pengguna sukarela akan tetapi konstruk ini menjadi signifikan ketika penggunaan teknologi diwajibkan([3]. Adapun model Utaut yang peneliti gunakan sebagai berikut:

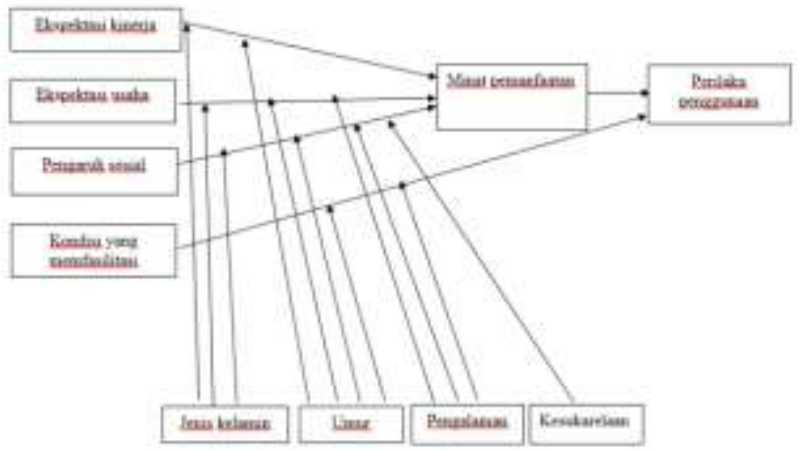

Gambar 1 Model UTAUT

\section{METODOLOGI PENELITIAN}

Metode penelitian ini merupakan penelitian survey. Lokasi penelitian dilakukan di Polresta Denpasar dimana subyek yang diteliti yaitu seluruh pengguna SIM Online di Lingkup Pelayanan Polresta Denpasar. Waktu Penelitian ini dilaksanakan pada tahun 2019.

Populasi dalam penelitia ini adalah pengguna SIM Online di lingkup pelayanan Polresta Denpasar, penelitian ini melakukan analisis dengan multivariate (korelasi atau regregasi ganda) maka jumlah anggota sampel minimal 10 kali dari jumlah variabel yang diteliti [4]. Maka rumus menentukan ukuran sampel dalam penelitian ini adalah :

$$
\begin{array}{ll}
\mathrm{N} & =10 \times \text { (independen }+ \text { dependen) } \\
\mathrm{N} & =10 \times 6 \\
\mathrm{~N} & =60
\end{array}
$$

Jadi jumlah sampel dalam penelitian ini yaitu 60 responden dengan menggunakan metode sampling insidental yaitu siapa saja yang secara kebetulan/insidental bertemu dengan peneliti dapat digunakan sebagai sampel, bila di pandang orang yang kebetulan ditemui itu cocok sebagai sumber data.

\subsection{Uji Coba Instrumen}

\subsubsection{Uji Gregory}

Uji Gregory digunakan untuk menentukan validitas isi instrumen. Teknik yang dikembangkan Gregory masih menggunakan penelitian pakar, namun hasil dalam pengujian isi yang sudah dikuantitatifkan. Mekanisme perhitungan pengujian validitas isi menurut Gregory adalah sebagai berikut:

a. Para pakar yang dipercaya menilai instrumen melakukan penilaian instrumen perbutir. b. Dilakukan pengelompokkan skala, kurang relavan dan sangat relavan

c. Hasil penilaian para pakar ditabulas dalam bentuk matriks

\subsubsection{Uji Validitas}

Uji validitas digunakan untuk mengukur sah atau valid tidaknya suatu kuesioner. Suatu kuesioner dinyatakan valid jika pertanyaan pada kuesioner mampu untuk mengungkapkan suatu yang akan diukur oleh kuesioner tersebut. Pengujian validitas data dalam penelitian ini dilakukan cara statistik yaitu menghitung korelasi antara masing-masing pertanyaan dengan skor total menggunakan Product Moment Pearson Correlation. Untuk mengetahui validitas butir, koefisien korelasi product moment(rxy) dibandingkan dengan harga rtabel . Jika rxy > rtabel maka butir dinyatakan valid karena terdapat korelasi yang signifikan antara skor butir dengan skor total.

\subsubsection{Uji Reliabilitas}

Reliabilitas sebenarnya adalah alat untuk mengukur suatu kuesioner yang merupakan indikator dari variabel atau konstruk. Suatu kuesioner dinyatakan reliabel atau handal jika jawaban seseorang terhadap pernyataan adalah konsisten atau stabil dari waktu ke waktu . Tahapan perhitungan reliabilitas menggunakan teknik Alpha Cronbach, karna teknik tersebut digunkaan untuk menghitung reliabilitas suatu tes yang mengukur sikap perilaku [5]

\subsection{Uji Asumsi Klasik}

\subsubsection{Uji Normalitas}

Uji normalitas dilakukan untuk mengetahui penyebaran data. Tujuannya untuk menghindari adanya bias dalam pengambilan keputusan. Pada prinsipnya normalitas dapat dideteksi dengan melihat penyebaran data pada sumbu diagonal dari grafik atau dengan melihat dari residalnya. Salah satu cara untuk melihat normalitas residualnya adalah dengan melihat normal probality plot. Cara normal probality plot dikatakan lebih handaldari pad acara grafik histogram, karena dta ini membandingkan data riil dengan data distribusi normal secara kumulatif [4].

\subsubsection{Uji Multikolinieritas}

Pengujian multikolinieritas ini berguna untuk mengetahui apakah model regresi ditemukan adanya korelasi antar variabel bebas. Model regresi yang baik seharusnya tidak terjadi korelasi diantara variabel bebas.Multikolinieritas dapat dilihat dari nilai Tolerancedan nilai Variance Inflation Factor(VIF). Kedua ukuran ini menunjukkan setiap varibel bebas manakah yang dijelaskan olehvariabel bebas lainnya. Di mana apabila nilaiTolerance $>0,10$ dan nilai $\mathrm{VIF}<10$ maka dapat dinyatakan bahwa tidak ada multikolinearitas antar variabel bebas dalam model regresi 


\subsubsection{Uji Liniearitas}

Pengujian linearitas digunakan untuk melihat apakah spesifikasi model yang digunakan sudah benar atau tidak. Apakah fungsi yang digunakan dalam suatu studi empiris sebaiknya berbentuk linear, kuadrat atau kubik. Dengan uji linearitas akan diperoleh informasi apakah model empiris sebaiknya linear, kuadrat atau kubik. Model regresi yang baik adalah regresi yang berbentuk linear.Pengujian normalitas data dalam penelitian ini menggunakan nilai Deviation From Linearity(DFL). Di mana apabila nilai sig. dari Deviation From Linearity $(\mathrm{DFL})>0,05$ maka dapat dinyatakan bahwa bentuk regresi linear.

\subsubsection{Uji Heterokeastisitas}

Pengujian heterokedastisitas untuk mengetahui apakah pada model regergasi terjadi ketidaksamaan variance dari residuak satu pengamatan ke pengamatan yang lain. Untuk mendeteksi ada tidaknya heterokedastisitas dilakukan dengan melihat grafik plot antara nilai prediksi variabel bebas (independen) yaitu ZPRED dengan residualnya SRESID[6].

\subsection{Uji Hipotesis}

\subsubsection{Regresi Linear Berganda}

Regregasi linier berganda dilakukan untuk mengetahui sejauh mana variabel bebas mempengaruhi varibael terikat sebagai berikut :

$\mathrm{Y}=\alpha+\mathrm{b} 1 \mathrm{X} 1+\mathrm{b} 2 \mathrm{X} 2+\mathrm{b} 3 \mathrm{X} 3+\mathrm{b} 4 \mathrm{X} 4+\varepsilon$

Keterangan :

$\begin{array}{ll}\mathrm{Y} & \text { : Keuntungan } \\ \alpha & \text { :Konstanta }\end{array}$

b1 b2 b3 b4 :Koefisien regregasi

$\mathrm{X} 1 \quad$ :Ekspektasi kinerja

X2 :Ekspektasi usaha

X3 :Pengaruh sosial

X4 :Kondisi yang memfasilitasi

$\varepsilon \quad$ :Eror

Uji regresi linier berganda terdiri dari uji secara simultan (Uji F) dan uji secara parsial (Uji-t). Uji F digunakan untuk mengetahui apakah variabel-variabel independen secara simultan berpengaruh signifikan terhadap variabel dependen. Uji tdigunakan untuk mengetahui apakah variabel-variabel ndependen secara parsial berpengaruh positifterhadap variabel dependen.

\subsubsection{Analisis Regresi (Uji Variabel Moderator)}

Uji variabel moderator bertujuan untuk mengetahui apakah variabel moderator jenis kelamin, umur dan pengalaman memiliki efek moderasi memperkuat atau memperlemah variabel bebas terhadap variabel terikat yaitu dengan melakukan dua kali regresi. Regresi pertama dilakukan antara variabel bebas dengan variabel terikat dan regresi kedua dilakukan dengan menambahkan variabel moderator serta menambahkan perkalian antara variabel moderator dengan variabel bebas setelah itubandingkan nilai $\mathrm{R}^{2}$ regresi pertama dengan nilai $\mathrm{R}^{2}$ regresi kedua ketika nilai $\mathrm{R}^{2}$ regresi pertama lebih kecil dari nilai $\mathrm{R}^{2}$ regresi kedua maka bisa dikatakan bahwa terdapat pengaruh variabel moderasi yang memperkuat hubungan antara variabel bebas dengan variabel terikat

\section{HASIL DAN PEMBAHASAN}

\subsection{HASIL PENELITIAN}

\subsubsection{Deskripsi Data}

Data penelitian dikumpulkan dengan cara membagikan kuesioner secara langsung kepada pengguna SIM Online. Kuisioner diperoleh dengan cara peneliti menemui langsung responden dan memberikan kuisioner langsung untuk diisi oleh pengguna SIM Online. Survey dengan pengguna dilakukan pada tanggal 31 Mei 2019 sampai dengan 20 Juni 2019 di Polresta Denpasar, dengan pengambilan 60 responden.

Data dalam penelitian ini terdiri dari beberapa variabel Ekspketasi Kinerja, Ekspektasi Usaha, Pengaruh Sosial, Kondisi yang Memfasilitasi, Minat Pemanfaatan dan Perilaku Pengguna. Model yang digunakan dalam penelitian [7]yang menguji pengaruh Ekspektasi Kinerja, Ekspektasi Usaha dan pengaruh sosial terhadap minat pemanfaatan serta kondisi yang memfasilitasi dan minat pemanfaatan terhadap perilaku pengguna juga peneliti gunakan dalam penelitian ini, tetapi dalam penelitiannya tidak menggunakan variabel moderator sedangkan dalam penelitian ini peneliti menggunakan variabel moderator di mana model ini sama dengan[3]. Model dalam penelitian ini sesuai dengan Gambar 2



\subsection{Uji Coba Instrumen}

\subsubsection{Uji Gregory}

Dalam penyusunan validitas instrumen dalam penelitian ini dilakukan uji validitas isi dengan melibatkan dua orang penilai. Uji validitas isi yang dilakukan menggunakan Uji Gregory yang ditabulasi dalam bentuk matriks seperti pada tabel 1berikut :

Tabel 1. Tabulasi Hasil Penilaian Kedua Penilai 
ISSN 2252-9063

Kumpulan Artikel Mahasiswa Pendidikan Teknik Informatika

(KARMAPATI)

\begin{tabular}{|l|l|l|l|}
\hline \multicolumn{2}{|l|}{ Pendai } & \multicolumn{2}{|l|}{ Pvailai 1 } \\
\cline { 3 - 4 } & Tadak Relevan & Relevas \\
\hline Penilai 2 & Tidak Releran & A & B \\
& & $(0)$ & $(1)$ \\
\cline { 3 - 4 } & Relevan & C & D \\
& & $(0)$ & $(27)$ \\
\hline
\end{tabular}

Validitas Isi $=\frac{D}{A+B+C+D}$

Validitas Isi $=\frac{27}{0+1+0+27}$

Validitas Isi $=\frac{27}{28}=0,96$

Jadi koefisien validitas isi instrumen yang diuji coba adalah 0,96 yang berkategori sangat tinggi hal ini dapat ditunjukkan pada acuan yang sudah di jelaskan di bagian bab 3 pada bagian uji validitas isi. Instrumen yang dinilai tidak relevan peneliti perbaiki sehingga semua instrumen dapat di ujicobakan.

\subsubsection{Uji Validitas}

Berdasarkan uji validitas yang dilakukan, dapat diketahui bahwa tigaitem pertanyaan tidak valid dan tidak diikutkan dalam pengambilan data pada sampel penelitian, dengan hasil pengujian selengkapnya, sebagai berikut :

Tabel 2 Hasil Uji Validitas Konstruk

\begin{tabular}{|l|l|l|l|l|}
\hline Variabel & $\begin{array}{l}\text { No } \\
\text { Item }\end{array}$ & $\begin{array}{l}\mathbf{R} \\
\text { table }\end{array}$ & $\begin{array}{l}\mathbf{R} \\
\text { hitung }\end{array}$ & Keterangan \\
\hline $\begin{array}{l}\text { Ekspektasi } \\
\text { Kinerja }\end{array}$ & 1 & 0,361 & 0,451 & Valid \\
\hline & 2 & 0,361 & 0,441 & Valid \\
\hline & 3 & 0,361 & 0,447 & Valid \\
\hline & 4 & 0,361 & 0,482 & Valid \\
\hline & 5 & 0,361 & 0,682 & Valid \\
\hline & 6 & 0,361 & 0,364 & Valid \\
\hline & 7 & 0,361 & 0,349 & Drop \\
\hline & 8 & 0,361 & 0,408 & Valid \\
\hline & 9 & 0,361 & 0,389 & Valid \\
\hline & 10 & 0,361 & 0,269 & Drop \\
\hline $\begin{array}{l}\text { Ekspektasi } \\
\text { Usaha }\end{array}$ & 11 & 0,361 & 0,571 & Valid \\
\hline & 12 & 0,361 & 0,558 & Valid \\
\hline & 13 & 0,361 & 0,559 & Valid \\
\hline & 14 & 0,361 & 0,463 & Valid \\
\hline & 15 & 0,361 & 0,416 & Valid \\
\hline & 16 & 0,361 & 0,460 & Valid \\
\hline $\begin{array}{l}\text { Pengaruh } \\
\text { Sosial }\end{array}$ & 17 & 0,361 & 0,427 & Valid \\
\hline & 18 & 0,361 & 0,283 & Drop \\
\hline
\end{tabular}

\begin{tabular}{|l|l|l|l|l|}
\hline Variabel & $\begin{array}{l}\text { No } \\
\text { Item }\end{array}$ & $\begin{array}{l}\mathbf{R} \\
\text { table }\end{array}$ & $\begin{array}{l}\mathbf{R} \\
\text { hitung }\end{array}$ & Keterangan \\
\hline & 19 & 0,361 & 0,447 & Valid \\
\hline & 20 & 0,361 & 0,376 & Valid \\
\hline & 21 & 0,361 & 0,522 & Valid \\
\hline & 22 & 0,361 & 0,480 & Valid \\
\hline $\begin{array}{l}\text { Kondisi yang } \\
\text { Memfasilitasi }\end{array}$ & 23 & 0,361 & 0,415 & Valid \\
\hline & 24 & 0,361 & 0,518 & Valid \\
\hline & 25 & 0,361 & 0,482 & Valid \\
\hline & 26 & 0,361 & 0,437 & Valid \\
\hline & 27 & 0,361 & 0,456 & Valid \\
\hline & 28 & 0,361 & 0,465 & Valid \\
\hline
\end{tabular}

Item untuk variabel Minat Pemanfaatan dan Perilaku Pengguna diturunkan berdasarkan item kuisioner dalam penelitian [8] yang disesuaikan dengan SIM Online.

\subsubsection{Uji Realiabilitas}

Uji reliabilitas dilakukan dengan menggunakan SPSS, yang melibatkan 25 butir pertanyaan yang valid setelah di analisis mendapatkan nilai cronbach alpha 0.959. Berasarkan kriteria tinggi rendahnya nilai koefisien reliabilitas, nilai cronbach alpha pada instrument ini termasuk dalam kategori sangat tinggi yaitu $0,91 \leq 0,959<1$. Setelah instrumen selesai diuji cobakan selanjutnya instrumen disebarkan ke sampel responden yang berjumlah 60 responden.

\subsection{Uji Asumsi Klasik}

\subsubsection{Uji Normalitas}

Uji normalitas menggunakan Kolmogrov-Smirnov, dapat diketahui bahwa nilai Asymp. Sig (2-tailed), sebagai berikut :

Tabel 3 Uji Normalitas Minat Pemanfaatan

\begin{tabular}{|l|l|}
\hline One-Sample Kolmogorov-Smirnov Test \\
\hline Asymp. Sig. (2-tailed) & $.899^{\text {c.d }}$ \\
\hline Tabel 4 Uji Normalitas Perilaku Pengguna \\
\begin{tabular}{|l|l|}
\hline One-Sample Kolmogorov-Smirnov Test \\
\hline Asymp. Sig. (2-tailed) & $.676^{\text {c.d }}$ \\
\hline
\end{tabular}
\end{tabular}

Uji normalitas berdasarkan minat pemanfaatan menggunakan Kolmogorov-Smirnov diatas menunjukkannilai Asymp. Sig. (2-tailed) sebesar 0,899 lebih besar dari 0,05. Sedangkan berdasarkan perilaku pengguna menunjukkan nilai Asymp. Sig. sebesar 0,876 lebih besar dari 0,05. Dengan kata lain dapat disimpulkan bahwa kedua data residual berdistribusi normal.

\subsubsection{Uji Multikolinearitas}

Uji multikolinearitas yang dilakukan, dapat dikeahui bahwa nilai tolerence dan nilai VIF untuk model regresi, sebagai berikut: 
Tabel 5 Uji Multikolinearitas Minat Pemanfaatan

\begin{tabular}{|l|l|l|l|}
\hline \multicolumn{4}{|c|}{ Coefficients $^{\mathrm{a}}$} \\
\hline \multicolumn{2}{|l|}{ Model } & \multicolumn{2}{|l|}{ Collinearity Statistics } \\
\cline { 3 - 4 } \multicolumn{2}{|c|}{1} & Tolerance & VIF \\
\hline \multirow{3}{*}{1} & (Constant) & & \\
\cline { 2 - 4 } & Ekspektasi Kinerja & .150 & 6.656 \\
\cline { 2 - 4 } & Ekspetasi Usaha & .277 & 3.614 \\
\cline { 2 - 4 } & Pengaruh Sosial & .225 & 4.453 \\
\hline
\end{tabular}

a. Dependent Variable: Minat Pemanfaatan

Tabel 6 Uji Multikolinearitas Perilaku Pengguna

\begin{tabular}{|c|c|c|c|}
\hline \multicolumn{4}{|c|}{ Coefficients $^{\mathrm{a}}$} \\
\hline \multirow{2}{*}{\multicolumn{2}{|c|}{ Model }} & \multicolumn{2}{|c|}{ Collinearity Statistics } \\
\hline & & Tolerance & VIF \\
\hline \multirow{3}{*}{1} & (Constant) & & \\
\hline & Kondisi Yang Memfasilitasi & .247 & 4.041 \\
\hline & Minat Pemanfaatan & .247 & 4.041 \\
\hline
\end{tabular}

a. Dependent Variable: Perilaku Pengguna

Uji multikolinearitas dengan nilai tolerancedan VIF diatas menunjukkan nilai tolerance masing-masing variabel lebih besar dari 0,10 dan nilai VIF masing-masing variabel kurang dari dari 10. Dengan kata lain dapat disimpulkan bahwa data yang digunakan tidak terjadi kasus multikolinearitas.

\subsubsection{Uji Linearitas}

Uji Linearitas menggunakan Deviation from Linearity(DFL). Dapat diketahui bahwa nilai sig. untuk DFL sebagai berikut :

Tabel 7 Uji Linearitas Minat Pemanfaatan

\begin{tabular}{|l|l|l|}
\hline \multicolumn{3}{|c|}{ ANOVA Table } \\
\hline \multicolumn{2}{|c|}{ Sig } \\
\hline $\begin{array}{l}\text { Minat Pemanfaatan } \\
\text { * Ekspektasi Kinerja }\end{array}$ & $\begin{array}{l}\text { Deviation from } \\
\text { Linearity }\end{array}$ & 0.094 \\
\hline $\begin{array}{l}\text { Minat Pemanfaatan } \\
\text { * Ekspektasi Usaha }\end{array}$ & $\begin{array}{l}\text { Deviation from } \\
\text { Linearity }\end{array}$ & 0.250 \\
\hline $\begin{array}{l}\text { Minat Pemanfaatan } \\
\text { * Pengaruh Sosial }\end{array}$ & $\begin{array}{l}\text { Deviation from } \\
\text { Linearity }\end{array}$ & 0.029 \\
\hline
\end{tabular}

Tabel 8 Uji Linearitas Perilaku Pengguna

\begin{tabular}{|l|l|l|}
\hline \multicolumn{3}{|c|}{ ANOVA Table } \\
\hline $\begin{array}{l}|c| \\
\text { Perilaku Pengguna * } \\
\text { Kondisi yang } \\
\text { memfasilitasi }\end{array}$ & $\begin{array}{l}\text { Deviation from } \\
\text { Linearity }\end{array}$ & 0.830 \\
\hline $\begin{array}{l}\text { Perilaku Pengguna * } \\
\text { Minat Pemanfaatan }\end{array}$ & $\begin{array}{l}\text { Deviation from } \\
\text { Linearity }\end{array}$ & 0.162 \\
\hline
\end{tabular}

Uji liniearitas dengan masing-masing nilai Sig. DFL masingmasing tabel di atas lebih besar dari 0,05. Dengan kata lain dapat disimpulkan bahwa data yang digunakan berbentuk regresi linear.

\subsubsection{Uji Heteroskedastisitas}

Uji heteroskedastisitas menggunakan Grafik Plot (scatterplot) dan uji Glejser, dapat diketahui bahwa nilai sig. untuk uji Glejer sebagai berikut:

Tabel 9 Uji Heteroskedastisitas Minat Pemanfaatan

\begin{tabular}{|c|c|c|}
\hline \multicolumn{3}{|c|}{ Coefficients $^{\mathrm{a}}$} \\
\hline \multicolumn{2}{|c|}{ Model } & Sig. \\
\hline \multirow{4}{*}{1} & (Constant) & \\
\hline & Ekspektasi Kinerja & .419 \\
\hline & Ekspektasi Usaha & .817 \\
\hline & Pengaruh Sosial & .148 \\
\hline
\end{tabular}

Tabel 10 Uji Heteroskedastisitas Perilaku Pengguna

\begin{tabular}{|c|l|l|}
\hline \multicolumn{2}{|c|}{ Coefficients $^{\mathrm{a}}$} \\
\hline Model & Sig. \\
\hline \multirow{3}{*}{1} & (Constant) & \\
\cline { 2 - 3 } & $\begin{array}{l}\text { Kondisi yang } \\
\text { Memfasilitasi }\end{array}$ & .175 \\
\cline { 2 - 3 } & Minat Pemanfaatan & .477 \\
\hline \multicolumn{2}{|c|}{ a.Dependent Variabel: Perpeng_ABS } \\
\hline
\end{tabular}

Uji heteroskedastisitas menggunakan uji glejser diatas memperoleh nilai sig. masing-masing variabel diatas 0,05 ( $>0,05)$. Dengan kata lain dapat disimpulkan bahwa data yang digunakan tidak terjadi heteroskedastisitas.

\subsection{Uji Hipotesis}

4.4.1 Uji kelayakan model (Uji F)

Tabel 11 hasil Uji F Minat Pemanfaatan

\begin{tabular}{|l|l|l|l|}
\hline \multicolumn{3}{|c|}{ ANOVA $^{\text {a }}$} \\
\hline \multirow{4}{*}{1} & Model & F & Sig. \\
\cline { 2 - 4 } & Regression & 179.739 & $.000^{\mathrm{b}}$ \\
\cline { 2 - 4 } & Residual & & \\
\cline { 2 - 3 } & Total & & \\
\cline { 2 - 3 } & a.Dependent Variabel: Minat Pemanfaatan \\
\cline { 2 - 3 } & \multicolumn{2}{l}{$\begin{array}{l}\text { b.Predictors (Constant), Ekspektasi Kinerja, } \\
\text { Ekspektasi Usaha, Pengaruh Sosial }\end{array}$} \\
\hline
\end{tabular}

Tabel 12 Hasil Uji F Perilaku Pengguna

\begin{tabular}{|l|l|l|l|}
\hline \multicolumn{3}{|c|}{ ANOVA $^{\text {a }}$} \\
\hline \multirow{4}{*}{1} & Model & F & Sig. \\
\cline { 2 - 4 } & Regression & 127.281 & $.000^{\mathrm{b}}$ \\
\cline { 2 - 4 } & Residual & & \\
\cline { 2 - 3 } & Total & & \\
\cline { 2 - 3 } & a.Dependent Variabel: Perilaku Pengguna \\
\cline { 2 - 3 } & $\begin{array}{l}\text { b.Predictors (Constant), Kondisi yang Memfasilitasi, } \\
\text { Minat Pemanfaatan }\end{array}$ \\
\hline
\end{tabular}

Berdasarkan pada tabel 11 dan 12 diketahui bahwa nilai masing-masing sig. adalah $0,000<0,05$ dapat disimpulkan bahwa ekspektasi kinerja, ekspektasi usaha, pengaruh sosial berpengaruh positif terhadap minat pemanfaatan. Dan kondisi yang memfasilitasi, minat pemanfaatan berpengaruh positif terhadap perilaku pengguna. 


\subsubsection{Uji Parsial (Uji t)}

Tabel 13. Hasil Uji t Minat Pemanfaatan

\begin{tabular}{|l|l|l|}
\hline \multicolumn{3}{|c|}{ Coefficients $^{\mathbf{a}}$} \\
\hline Model & $\mathrm{t}$ & Sig. \\
\hline (Constant) & -1.793 & .078 \\
\hline Ekspektasi Kinerja & 5.416 & .000 \\
\hline Ekspektasi Usaha & 2.410 & .019 \\
\hline Pengaruh Sosial & 2.718 & .009 \\
\hline \multicolumn{2}{|l|}{ a.Dependent Variabel Minat Pemanfaatan } \\
\hline
\end{tabular}

Tabel 14. Hasil Uji t Perilaku Pengguna

\begin{tabular}{|l|l|l|}
\hline \multicolumn{3}{|c|}{ Coefficients $^{\mathbf{a}}$} \\
\hline Model & $\mathrm{t}$ & Sig. \\
\hline (Constant) & .747 & .458 \\
\hline $\begin{array}{l}\text { Kondisi yang } \\
\text { Memfasilitasi }\end{array}$ & 6.016 & .000 \\
\hline Minat Pemanfaatan & 2.132 & .037 \\
\hline \multicolumn{2}{|l|}{ a.Dependent Variabel Perilaku Pengguna } \\
\hline
\end{tabular}

Berdasarkan Tabel diatas dapat disimpulkan sebagai berikut:

1. Variabel ekspektasi kinerja mempunya nilai sig. 0,000 < 0,05 artinya secara parsial variabel ekspektasi kinerja berpengaruh positif dan signifikan terhadap minat pemanfaatan.

2. Variabel ekspektasi usaha mempunyai nilai sig. 0,019 < 0,05 artinya secara parsil variabel ekspektasi usaha berpengaruh positif dan signifikan terhadap minat pemanfaatan.

3. Variabel pengaruh sosial mempunyai nilai sig. $0,009<$ 0,05 artinya secara parsil variabel pengaruh sosial berpengaruh positif dan signifikan terhadap minat pemanfaatan.

4. Variabel kondisi yang memfasilitasi mempunyai nilai sig. $0,000<0,05$ artinya secara parsil variabel kondisi yang memfasilitasi berpengaruh positif dan signifikan terhadap perilaku pengguna.

5. Varibel minat pemanfaatan mempunyai nilai sig. 0,037 < artinya secara parsial variabel minat pemanfaatan berpengaruh positif dan signifikan terhadap perilaku pengguna.

\subsubsection{Analisis Regresi (Uji Variabel Moderator)}

1. Variabel moderator jenis kelamin mempengaruhi hubungan ekspektasi kinerja terhadap minat pemanfaatan

Tabel 15 Regresi pertama ekspektasi kinerja terhadap minat pemanfaatan

\begin{tabular}{|l|l|l|l|l|}
\hline \multicolumn{5}{|c|}{ Model Summary } \\
\hline Model & $\mathrm{R}$ & R Square & $\begin{array}{l}\text { Adjusted } \\
\text { R Square }\end{array}$ & $\begin{array}{l}\text { Std. Error of the } \\
\text { Estimate }\end{array}$ \\
\hline 1 & $.939^{\mathrm{a}}$ & .882 & .880 & 1.326 \\
\hline \multicolumn{5}{|c|}{ a.Predictors: (Constant), Ekspektasi Kinerja } \\
\hline
\end{tabular}

Tabel 16 Regresi kedua penambahan variabel moderator jenis kelamin

\begin{tabular}{|l|l|l|l|l|}
\hline \multicolumn{5}{|c|}{ Model Summary } \\
\hline Model & $\mathrm{R}$ & $\begin{array}{l}\mathrm{R} \\
\text { Square }\end{array}$ & $\begin{array}{l}\text { Adjusted R } \\
\text { Square }\end{array}$ & $\begin{array}{l}\text { Std. Error of } \\
\text { the Estimate }\end{array}$ \\
\hline 1 & $.941^{\mathrm{a}}$ & .885 & .881 & 1.320 \\
\hline \multicolumn{4}{|c|}{ a.Predictors: (Constant), Jenis Kelamin, Ekspektasi Kinerja } \\
\hline
\end{tabular}
Berdasarkan hasil uji regresi pertama dan kedua pada Tabel 15 dan Tabel 16 regresi pertama 0,882 sedangkan setelah ada penambahan moderator maka nilai kedua regresi berubah menjadi 0,885 . Sehingga keputusan uji bahwa jenis kelamin memiliki efek moderasi yang memperkuat hubungan ekspektasi kinerja terhadap minat pemanfaatan.

2. Variabel moderator jenis kelamin mempengaruhi hubungan ekspektasi usaha terhadap minat pemanfaatan

Tabel 17 Regresi pertama ekspektasi usaha terhadap minat pemanfaatan

\begin{tabular}{|l|l|l|l|l|}
\hline \multicolumn{5}{|c|}{ Model Summary } \\
\hline Model & $\mathrm{R}$ & R Square & $\begin{array}{l}\text { Adjusted } \\
\text { R Square }\end{array}$ & $\begin{array}{l}\text { Std. Error of the } \\
\text { Estimate }\end{array}$ \\
\hline 1 & $.854^{\mathrm{a}}$ & .730 & .725 & 2.008 \\
\hline
\end{tabular}

a.Predictors: (Constant), Ekspektasi Usaha

Tabel 18 Regresi kedua penambahan variabel moderator jenis kelamin

\begin{tabular}{|l|l|l|l|l|}
\hline \multicolumn{5}{|c|}{ Model Summary } \\
\hline Model & $\mathrm{R}$ & R Square & $\begin{array}{l}\text { Adjusted } \\
\text { R Square }\end{array}$ & $\begin{array}{l}\text { Std. Error of the } \\
\text { Estimate }\end{array}$ \\
\hline 1 & $.855^{\mathrm{a}}$ & .731 & .721 & 2.022 \\
\hline
\end{tabular}

a.Predictors: (Constant), Jenis Kelamin ,Ekspektasi Usaha

Berdasarkan hasil uji regresi pertama dan kedua pada Tabel 17 dan Tabel 18 regresi pertama 0,730 sedangkan setelah ada penambahan moderator maka nilai kedua regresi berubah menjadi 0,731. Sehingga dapat disimpulkan bahwa jenis kelamin memiliki efek moderasi yang memperkuat hubungan ekspektasi usaha terhadap minat pemanfaatan.

3. Variabel moderator jenis kelamin mempengaruhi hubungan pengaruh sosial terhadap minat pemanfaatan

Tabel 19 Regresi pertama pengaruh sosial terhadap minat pemanfaatan

\begin{tabular}{|l|l|l|l|l|}
\hline \multicolumn{5}{|c|}{ Model Summary } \\
\hline Model & $\mathrm{R}$ & R Square & $\begin{array}{l}\text { Adjusted } \\
\text { R Square }\end{array}$ & $\begin{array}{l}\text { Std. Error of the } \\
\text { Estimate }\end{array}$ \\
\hline 1 & $.936^{\mathrm{a}}$ & .877 & .875 & 1.356 \\
\hline \multicolumn{5}{|c|}{ a.Predictors: (Constant), Pengaruh Sosial } \\
\hline
\end{tabular}


Tabel 20 Regresi kedua penambahan variabel moderator jenis kelamin

\begin{tabular}{|l|l|l|l|l|}
\hline \multicolumn{5}{|c|}{ Model Summary } \\
\hline Model & $\mathrm{R}$ & R Square & $\begin{array}{l}\text { Adjusted } \\
\text { R Square }\end{array}$ & $\begin{array}{l}\text { Std. Error of the } \\
\text { Estimate }\end{array}$ \\
\hline 1 & $.939^{\mathrm{a}}$ & .881 & .877 & 1.343 \\
\hline \multicolumn{4}{|c|}{ a.Predictors: (Constant), Jenis Kelamin, Pengaruh Sosial }
\end{tabular}

Berdasarkan hasil uji regresi pertama dan kedua pada Tabel 19 dan Tabel 20 regresi pertama 0,877 sedangkan setelah ada penambahan moderator maka nilai kedua regresi berubah menjadi 0,881. Sehingga jenis kelamin memiliki efek moderasi yang memperkuat hubungan pengaruh sosial terhadap minat pemanfaatan.

4. Variabel umur mempengaruhi hubungan ekspektasi kinerja terhadap Minat Pemanfaatan.

Tabel 21 Regresi pertama ekspektasi kinerja terhadap minat pemanfaatan

\begin{tabular}{|l|l|l|l|l|}
\hline \multicolumn{5}{|c|}{ Model Summary } \\
\hline Model & $\mathrm{R}$ & $\begin{array}{l}\mathrm{R} \\
\text { Square }\end{array}$ & $\begin{array}{l}\text { Adjusted R } \\
\text { Square }\end{array}$ & $\begin{array}{l}\text { Std. Error of } \\
\text { the Estimate }\end{array}$ \\
\hline 1 & $.939^{\mathrm{a}}$ & .882 & .880 & 1.326 \\
\hline \multicolumn{4}{|c|}{ a.Predictors: (Constant), Ekspektasi Kinerja } \\
\hline
\end{tabular}

Tabel 22 Regresi kedua penambahan variabel moderator umur

\begin{tabular}{|l|l|l|l|l|}
\hline \multicolumn{5}{|c|}{ Model Summary } \\
\hline Model & $\mathrm{R}$ & $\begin{array}{l}\mathrm{R} \\
\text { Square }\end{array}$ & $\begin{array}{l}\text { Adjusted R } \\
\text { Square }\end{array}$ & $\begin{array}{l}\text { Std. Error of } \\
\text { the Estimate }\end{array}$ \\
\hline 1 & $.939^{\mathrm{a}}$ & .882 & .878 & 1.337 \\
\hline \multicolumn{4}{|c|}{ a.Predictors: (Constant), Umur, Ekspektasi Kinerja } \\
\hline
\end{tabular}

Berdasarkan hasil uji regresi pertama dan kedua pada Tabel 21 dan Tabel 22 regresi pertama 0,882 sedangkan setelah ada penambahan moderator nilai kedua regresi tetap sama menjadi 0,882 . Sehingga dapat disimpulkan bahwa umur memiliki efek moderasi yang tidak memperkuat atau memperlemah hubungan ekspektasi kinerja terhadap minat pemanfaatan.

5. Variabel umur mempengaruhi hubungan ekspektasi usaha terhadap Minat Pemanfaatan.

Tabel 23 Regresi pertama ekspektasi usaha terhadap minat pemanfaatan

\begin{tabular}{|l|l|l|l|l|}
\hline \multicolumn{5}{|c|}{ Model Summary } \\
\hline Model & $\mathrm{R}$ & $\begin{array}{l}\mathrm{R} \\
\text { Square }\end{array}$ & $\begin{array}{l}\text { Adjusted R } \\
\text { Square }\end{array}$ & $\begin{array}{l}\text { Std. Error of } \\
\text { the Estimate }\end{array}$ \\
\hline 1 & $.854^{\mathrm{a}}$ & .730 & .725 & 2.008 \\
\hline \multicolumn{5}{|c|}{ a.Predictors: (Constant), Ekspektasi Usaha } \\
\hline
\end{tabular}

Tabel 24 Regresi kedua penambahan variabel moderator umur

\begin{tabular}{|l|l|l|l|l|}
\hline \multicolumn{5}{|c|}{ Model Summary } \\
\hline Model & $\mathrm{R}$ & $\begin{array}{l}\mathrm{R} \\
\text { Square }\end{array}$ & $\begin{array}{l}\text { Adjusted R } \\
\text { Square }\end{array}$ & $\begin{array}{l}\text { Std. Error of } \\
\text { the Estimate }\end{array}$ \\
\hline 1 & $.855^{\text {a }}$ & .732 & .722 & 2.108 \\
\hline \multicolumn{5}{|c|}{ a.Predictors: (Constant), Umur, Ekspektasi Usaha } \\
\hline
\end{tabular}

Berdasarkan hasil uji regresi pertama dan kedua pada Tabel 23 dan Tabel 24 regresi pertama 0,730 sedangkan setelah ada penambahan moderator maka nilai kedua regresi berubah menjadi 0,732 . Sehingga disimpulkan bahwa umur memiliki efek moderasi yang memperkuat hubungan ekspektasi usaha terhadap minat pemanfaatan.

6. Variabel umur mempengaruhi hubungan pengaruh sosial terhadap Minat Pemanfaatan.

Tabel 25 Regresi pertama pengaruh sosial terhadap minat pemanfaatan

\begin{tabular}{|l|l|l|l|l|}
\hline \multicolumn{5}{|c|}{ Model Summary } \\
\hline Model & $\mathrm{R}$ & $\begin{array}{l}\mathrm{R} \\
\text { Square }\end{array}$ & $\begin{array}{l}\text { Adjusted R } \\
\text { Square }\end{array}$ & $\begin{array}{l}\text { Std. Error of } \\
\text { the Estimate }\end{array}$ \\
\hline 1 & $.936^{\mathrm{a}}$ & .877 & .875 & 1.356 \\
\hline \multicolumn{5}{|c|}{ a.Predictors: (Constant), Pengaruh Sosial } \\
\hline
\end{tabular}

Tabel 26 Regresi kedua penambahan variabel moderator umur

\begin{tabular}{|l|l|l|l|l|}
\hline \multicolumn{5}{|c|}{ Model Summary } \\
\hline Model & $\mathrm{R}$ & $\begin{array}{l}\mathrm{R} \\
\text { Square }\end{array}$ & $\begin{array}{l}\text { Adjusted R } \\
\text { Square }\end{array}$ & $\begin{array}{l}\text { Std. Error of } \\
\text { the Estimate }\end{array}$ \\
\hline 1 & $.940^{\mathrm{a}}$ & .884 & .880 & 1.327 \\
\hline
\end{tabular}

a.Predictors: (Constant), Umur,Pengaruh Sosial

Berdasarkan hasil uji regresi pertama dan kedua pada Tabel 25 dan Tabel 26 regresi pertama 0,877 sedangkan setelah ada penambahan moderator maka nilai kedua regresi berubah menjadi 0,884. Sehingga dapat disimpulkan bahwa umur memiliki efek moderasi yang memperkuat hubungan pengaruh sosial terhadap minat pemanfaatan.

7. Variabel umur mempengaruhi hubungan kondisi yang memfasilitasi terhadap Perilaku Pengguna

Tabel 27 Regresi pertama pengaruh kondisi yang memfasilitasi terhadap minat pemanfaatan

\begin{tabular}{|l|l|l|l|l|}
\hline \multicolumn{5}{|c|}{ Model Summary } \\
\hline Model & $\mathrm{R}$ & $\begin{array}{l}\mathrm{R} \\
\text { Square }\end{array}$ & $\begin{array}{l}\text { Adjusted R } \\
\text { Square }\end{array}$ & $\begin{array}{l}\text { Std. Error of } \\
\text { the Estimate }\end{array}$ \\
\hline 1 & $.896^{\mathrm{a}}$ & .802 & .799 & 1.025 \\
\hline
\end{tabular}

a.Predictors: (Constant), kondisi yang memfasilitasi

Tabel 28 Regresi kedua penambahan variabel moderator umur Model Summary

\begin{tabular}{|l|l|l|l|l|}
\hline Model & $\mathrm{R}$ & $\begin{array}{l}\mathrm{R} \\
\text { Square }\end{array}$ & $\begin{array}{l}\text { Adjusted R } \\
\text { Square }\end{array}$ & $\begin{array}{l}\text { Std. Error of } \\
\text { the Estimate }\end{array}$ \\
\hline 1 & $.899^{\mathrm{a}}$ & .802 & .802 & 1.016 \\
\hline
\end{tabular}

a.Predictors: (Constant), umur, kondisi yang memfasilitasi

Berdasarkan hasil uji regresi pertama dan kedua pada Tabel 27 dan Tabel 28 regresi pertama 0,802 sedangkan setelah ada penambahan moderator maka nilai kedua regresi berubah menjadi 0,809. Sehingga dapat disimpulkan bahwa umur memiliki efek moderasi yang memperkuat hubungan kondisi yang memfasilitasi terhadap perilaku pengguna. 
8. Variabel pengalaman mempengaruhi hubungan ekspektasi usaha terhadap Minat Pemanfaatan

Tabel 29 Regresi pertama ekspektasi usaha terhadap Minat Pemanfaatan

\begin{tabular}{|l|l|l|l|l|}
\hline \multicolumn{5}{|c|}{ Model Summary } \\
\hline Model & $\mathrm{R}$ & $\begin{array}{l}\mathrm{R} \\
\text { Square }\end{array}$ & $\begin{array}{l}\text { Adjusted R } \\
\text { Square }\end{array}$ & $\begin{array}{l}\text { Std. Error of } \\
\text { the Estimate }\end{array}$ \\
\hline 1 & $.854^{\mathrm{a}}$ & .730 & .725 & 2.008 \\
\hline \multicolumn{4}{|c|}{ a.Predictors: (Constant), Ekspektasi Usaha } \\
\hline
\end{tabular}

Tabel 30 Regresi kedua penambahan variabel moderator pengalaman

\begin{tabular}{|l|l|l|l|l|}
\hline \multicolumn{5}{|c|}{ Model Summary } \\
\hline Model & $\mathrm{R}$ & $\begin{array}{l}\mathrm{R} \\
\text { Square }\end{array}$ & $\begin{array}{l}\text { Adjusted R } \\
\text { Square }\end{array}$ & $\begin{array}{l}\text { Std. Error of } \\
\text { the Estimate }\end{array}$ \\
\hline 1 & $.855^{\mathrm{a}}$ & .731 & .721 & 2.022 \\
\hline \multicolumn{4}{|c|}{ a.Predictors: (Constant), Pengalaman * Ekspektasi Usaha } \\
\hline
\end{tabular}

Berdasarkan hasil uji regresi pertama dan kedua pada Tabel 29 dan Tabel 30 regresi pertama 0,730 sedangkan setelah ada penambahan moderator maka nilai kedua regresi berubah menjadi 0,731 Sehingga dapat disimpulkan bahwa pengalaman memiliki efek moderasi yang memperkuat hubungan ekspektasi usaha terhadap minat pemanfaatan. 9. Variabel pengalaman mempengaruhi hubungan pengaruh sosial terhadap Minat Pemanfaatan

Tabel 31 Regresi Pertama pengaruh sosial terhadap Minat Pemanfaatan

\begin{tabular}{|l|l|l|l|l|}
\hline \multicolumn{5}{|c|}{ Model Summary } \\
\hline Model & $\mathrm{R}$ & $\begin{array}{l}\mathrm{R} \\
\text { Square }\end{array}$ & $\begin{array}{l}\text { Adjusted R } \\
\text { Square }\end{array}$ & $\begin{array}{l}\text { Std. Error of } \\
\text { the Estimate }\end{array}$ \\
\hline 1 & $.936^{\mathrm{a}}$ & .877 & .875 & 1.356 \\
\hline \multicolumn{5}{|c|}{ a.Predictors: (Constant), Pengaruh Sosial } \\
\hline
\end{tabular}

Tabel 32 Regresi kedua penambahan variabel moderator pengalaman

\begin{tabular}{|l|l|l|l|l|}
\hline \multicolumn{5}{|c|}{ Model Summary } \\
\hline Model & $\mathrm{R}$ & $\begin{array}{l}\mathrm{R} \\
\text { Square }\end{array}$ & $\begin{array}{l}\text { Adjusted R } \\
\text { Square }\end{array}$ & $\begin{array}{l}\text { Std. Error of } \\
\text { the Estimate }\end{array}$ \\
\hline 1 & $.939^{\mathrm{a}}$ & .881 & .877 & 1.343 \\
\hline \multicolumn{5}{|c|}{ a.Predictors: (Constant), Pengalaman*Pengaruh Sosial } \\
\hline
\end{tabular}

Berdasarkan hasil uji regresi pertama dan kedua pada Tabel 31 dan Tabel 32 regresi pertama 0,877 sedangkan setelah ada penambahan moderator maka nilai kedua regresi berubah menjadi 0,881 Sehingga dapat disimpulkan bahwam pengalaman memiliki efek moderasi yang memperkuat hubungan pengaruh sosial terhadap minat pemanfaatan.

10. Variabel pengalaman mempengaruhi hubungan kondisi yang memfasilitasi terhadap Perilaku Pengguna

Tabel 33 Regresi Pertama kondisi yang memfasilitasi terhadap Perilaku Pengguna

\begin{tabular}{|l|l|l|l|l|}
\hline \multicolumn{5}{|c|}{ Model Summary } \\
\hline Model & $\mathrm{R}$ & $\begin{array}{l}\mathrm{R} \\
\text { Square }\end{array}$ & $\begin{array}{l}\text { Adjusted R } \\
\text { Square }\end{array}$ & $\begin{array}{l}\text { Std. Error of } \\
\text { the Estimate }\end{array}$ \\
\hline 1 & $.896^{\mathrm{a}}$ & .802 & .799 & 1.025 \\
\hline
\end{tabular}

a.Predictors: (Constant), Kondisi yang Memfasilitasi

Tabel 34 Regresi kedua penambahan variabel moderator pengalaman

\begin{tabular}{|l|l|l|l|l|}
\hline \multicolumn{5}{|c|}{ Model Summary } \\
\hline Model & $\mathrm{R}$ & $\begin{array}{l}\text { R } \\
\text { Square }\end{array}$ & $\begin{array}{l}\text { Adjusted R } \\
\text { Square }\end{array}$ & $\begin{array}{l}\text { Std. Error of } \\
\text { the Estimate }\end{array}$ \\
\hline 1 & $.898^{\mathrm{a}}$ & .806 & .799 & 1.025 \\
\hline
\end{tabular}

a.Predictors: (Constant), Pengalaman* Kondisi yang

Memfasilitasi

Berdasarkan hasil uji regresi pertama dan kedua pada Tabel 33 dan Tabel 34 regresi pertama 0,802 sedangkan setelah ada penambahan moderator maka nilai kedua regresi berubah menjadi 0,806. Sehingga dapat disimpulkan bahwa pengalaman memiliki efek moderasi yang memperkuat hubungan kondisi yang memfasilitasi terhadap perilaku pengguna.

\subsection{Pembahasan}

\subsubsection{Pembahasan Hasil Uji Regresi Berdasarkan Minat Pemanfaatan}

Terdapat tiga hipotesis yang ditemukan dari hasil uji regresi berdasarkan minat pemanfaatan :

1. Ekspektasi Kinerja terhadap minat pemanfaatan SIM Online

Ekspektasi kinerja pengguna SIM Online mempunyai koefisien regresi yang ditunjukkan pada Tabel 13 yang berarti hipotesis diterima bahwa faktor ekspektasi kinerja berpengaruh positif terhadap minat pemanfaatan SIM Online.

Ekspektasi kinerja dalam penelitian ini yaitu berhubungan dengan kegunaan pengguna SIM Online yang dirasa dapat meningkatkan kinerjanya, persepsi yang diinginkan pengguna untuk menggunakan SIM Online, kesesuaian SIM Online meningkatkan kinerja pekerjaannya dan keuntungan yang di dapatkan ketika menggunakan SIM Online. Berdasarkan hasil pengukuran variabel ekspektasi kinerja diperoleh $28.13 \%$ pengguna sanggat setuju, $24.22 \%$ setuju, $12.32 \%$ kurang setuju, $27.10 \%$ tidak setuju, 8,23\% sangat tidak setuju. Berdasarkan penemuan dilapangan pengguna memberikan penjelasan bahwa pelayanan SIM Online yang belum optimal digunakan karena terkait dengan perbedaan persepsi dimana pihak polresta mengingikan pengguna print out langsung bukti pendaftaran, tetapi kebanyakan pengguna hanya menunjukkan bukti pendaftaran melalui handphone.

Penelitian ini juga sejalan dengan penelitian" Analisis Pengaruh Variabel Model Utaut Terhadap Penerimaan Dan Penggunaan Aplikasi Badan Penyelenggara Jaminan Sosial" di mana ekspektasi kinerja berpengaruh positif dan signifikan terhadap minat pemanfaatan aplikasi BPJS [9], penelitian lainnya dengan judul "Analisis Penerimaan Dan Penggunaan Sistem Informasi Akademik Melalui Pengembangan Model Utaut " di mana penggunaan teknologi informasi secara baik dan benar, serta sistematis 
akan memberikan dampak yang besar dalam hal membantu kinerja bagi penggunanya. [7], berbeda dengan penelitan [10] berdasarkan hasil penelitian telah diketahui bahwa variabel permonce expectancy (ekspektasi kinerja) tidak berpengaruh positif terhadap behavioral intention (minat pemanfaatan), sehingga dikatakan bahwa pengguna tidak merasakan manfaat dalam menggunakan Wondroid untuk dapat meningkatkan kinerjanya.

\section{Ekspektasi Usaha terhadap Minat Pemanfaatan SIM Online}

Ekspektasi usaha pengguna SIM Online mempunyai koefisien regresi yang ditunjukkan pada Tabel 13 yang berarti hipotesis diterima bahwa faktor ekspektasi usaha berpengaruh positif terhadap minat pemanfaatan SIM Online. Ekspektasi usaha dalam penelitian ini berdasarkan deskripsi yaitu kemudahan yang dirasakan pengguna seberapa jauh pengguna percaya bahwa menggunakan SIM Online akan bebas dari usaha, kerumitan seberapa jauh SIM Online dianggap sebagai sesuatu sistem yang susah untuk dipahami, dan kemudahan penggunan seberapa jauh suatu sistem dipersepsikan sebagai sesuatu yang mudah untuk dipahami dan digunakan.

Berdasarkan data penelitian dari hasil pengukuran variabel ekspektasi usaha diperoleh $25.90 \%$ pengguna sangat setuju, $24.52 \%$ setuju, $12.81 \%$ kurang setuju, 29.25 tidak setuju $7.26 \%$ sangat tidak setuju. Variabel ekspektasi usaha dengan indikator kerumitan memperoleh skor tertinggi dengan total 402, yang berarti bahwa pengguna percaya bahwa menggunakan SIM Online tidak membutuhkan waktu yang lama dalam proses pendaftaran atau perpanjangan SIM. Selain itu pengguna juga percaya bahwa menggunakan SIM Online mudah untuk dipahami. Namun berbanding terbalik dalam indikator kemudahan yang dirasakan pengguna memperoleh nilai 395 hal ini sesuai dengan penyebaran kuesioner dan beberapa hasil wawancara ke pengguna, pengguna sendiri merasa belum mengetahui secara khusus apa saja yang bisa dibawa pada saat pendaftaran Online tersebut. Pengguna sendiri masih banyak yang tidak memahaminya. Maka dari itu alangkah baiknya jika Polresta membuat spanduk mengenai langkah-langkah dan persyaratan yang harus dibawa pada saat melakukan pendaftaran Online agar pengguna merasakan kemudahan yang dirasakan pada saat melakukan pendaftaran atau perpanjangan sim.

Penelitian ini juga sejalan dengan penelitian [11] yang menyatakan bahwa kemudahan pengguna dalam menggunakan sistem ERP dan kompleksitas sistem ERP, memiliki pengaruh terhadap penerimaan pengguna. Penelitian lainnya dari [9] yang menyatakan bahwa variabel effort expectacy berpengaruh secara signifikan terhadap behavioral intention dari pengguna dalam menggunakan sebuah aplikasi BPJS. Berbeda dengan penelitian dari [12] yang menyatakan tidak adanya pengaruh yang signifikan terhadap behavioral intention e-commerce XYZ.

\section{Pengaruh Sosial terhadap Minat Pemanfaatan SIM Online}

Pengaruh sosial pengguna SIM Online mempunyai koefisien regresi yang ditunjukkan pada Tabel 13 yang berarti hipotesis diterima bahwa faktor pengaruh sosial berpengaruh positif terhadap minat pemanfaatan SIM Online.

Pengaruh sosial dalam penelitian ini yaitu sejauh mana seseorang dipengaruhi oleh orang lain untuk menggunakan suatu sistem informasi yang dalam penelitian ini yait SIM Online. Berdasarkan data penelitian dari hasil pengukuran variabel pengaruh sosial diperoleh $40.53 \%$ pengguna sangat setuju, $18.27 \%$ setuju, $16.94 \%$ kurang setuju, $20.59 \%$ tidak setuju, $3.67 \%$ sangat tidak setuju. Berdasarkan hasil penyebaran kuesioner dan beberapa hasil wawancara ke pengguna, pengguna sendiri menyampaikan bahwa ada orang lain yang dapat mempengaruhinya dalam menggunakan SIM Online. Bahwa ketertarikan pengguna menggunakan SIM Online berawal dari postingan teman di media sosial.

Penelitian ini sejalan dengan penelitian [12] yang menyatakan bahwa social influence memiliki hubungan korelasi terhadap behavioral intention. Penelitian lainnya dari [11] yang menyatakan bahwa faktor social influence memberikan pengaruh dalam penerimaan pengguna karena pengguna memerlukan pengaruh dari orang lain untuk menggunakan sistem ERP.

\subsubsection{Pembahasan Hasil Uji Regresi Berdasarkan Perilaku Pengguna}

1. Kondisi yang memfasilitasi terhadap perilaku pengguna

Kondisi yang memfasilitasi mempunyai koefisien regresi yang ditunjukkan pada Tabel 14 yang berarti hipotesis diterima bahwa faktor kondisi yang memfasilitasi berpengaruh positif terhadap perilaku pengguna. Faktor kondisi yang memfasilitasi dalam penelitian ini yaitu persepsi kendala internal dan eksternal terhadap perilaku, kondisi pemfasilitas, internet kesesuaian dengan kebutuhan dalam menggunakan SIM Online.

Berdasarkan data penelitian dari hasil pengukuran variabel kondisi yang memfasilitasi diperoleh $30.08 \%$ pengguna sangat setuju, $29.80 \%$ setuju, 11.97 kurang setuju, 22.84\% tidak setuju, $5.31 \%$ sangat tidak setuju. Variabel kondisi yang memfasilitasi dengan indikator kesesuaian dengan kebutuhan memperoleh nilai tertinggi yaitu 442, hal ini berarti pengguna tertarik menggunakn sistem tergantung pada sejauh mana inovasi dalam sistem tersebut dan kesesuaian dengan kebutuhan pekerjaan yang dilakukan. Dari hasil penyebaran kuesioner pengguna percaya bahwa menggunakan SIM Online dapat meningkatkan produktivitas pekerjaannya. Namun dalam hal ini berbanding terbalik dalam kondisi pemfasiltas, dimana pengguna belum merasakan fasilitas yang disediakan dipolresta denpasar. 
Penelitian ini sejalan dengan penelitian dari [13] yang menyatakan bahwa minat pemanfaatan (behavioral intention) berpengaruh positif terhadap perilaku pengguna (Use Behavior) sistem Garsupati yaitu pengguna mempunyai keinginan menggunakan sistem Garsupati untuk waktu yang akan datang. Sejalan dengan penelitian dari [14] yang menyatakan bahwa kondisi yang memfasilitasi berpengaruh positif terhadap penggunaan Sistem Informasi Daerah di sekretariat Daerah Kabupaten Gianyar. Hasil ini menunjukkan bahwa kondisi pendukung yang baik terhadap penggunaan Sistem Informasi Daerah seperti ketersediaan internet ataupun komputer yang mendukung dari penggunaan Sistem Informasi Daerah.

\section{Minat pemanfaatan terhadap perilaku pengguna}

Minat pemanfaatan mempunyai koefisien regresi yang ditunjukkan pada Tabel 14 yang berarti hipotesis diterima bahwa minat pemanfaatan berpengaruh positif terhadap perilaku pengguna. Minat pemanfaatan dalam penelitian ini yaitu tingkat keinginan atau niat pengguna untuk menggunakan teknologi informasi yang dapat mempengaruhi tingkat kinerja pengguna. Dalam hal ini pengguna mempunyai keinginan menggunakan SIM Online untuk waktu yang akan datang. Berdasarkan dari hasil pengukuran variabel minat pemanfaatan diperoleh $21.22 \%$ pengguna sangat setuju, 28.49 $\%$ setuju, $10.61 \%$ kurang setuju $27.37 \%$ tidak setuju, $12.31 \%$ sangat tidak setuju. Variabel minat pemanfaatan memiliki persepsi bahwa pengguna mempunyai keinginan menggunakan SIM Online untuk waktu yang akan datang dengan nilai tertinggi yaitu 208.

Penelitian ini sejalan dengan penelitian [9] yang menyatakan bahwa behavioral intention memberikan pengaruh yang signifikan terhadap use behavioral terhadap aplikasi BPJS. Penlitian lainnya dari [15] yang menyatakan minat pemanfaatan untuk menggunakan aplikasi transportasi online dan sikap pengguna yang menerima penggunaan aplikasi transportasi online dan prilaku pengguna juga mempengaruhi sikap user dalam menggunakan aplikasi transportasi online kemudahan dalam penggunaan aplikasi transportasi online, menjadikan siapaun dapat menggunakan tanpa membutuhkan pelatihan khusus.

\subsubsection{Pembahasan Moderator Jenis Kelamin}

1. Variabel moderator jenis kelamin mempengaruhi variabel ekspektasi kinerja terhadap minat pemanfaatan

Variabel moderator jenis kelamin mempengaruhi ekspektasi kinerja terhadap minat pemanfaatan mendapatkan hasil regresi pertama dan kedua mengalami peningkatan ditunjukkan pada Tabel 15 dan Tabel 16. Dikarenakan ada peningkatan antara variabel pertama dan kedua, artinya jenis kelamin memiliki efek moderasi yang memperkuat hubungan ekspektasi kinerja terhadap minat pemanfaatan SIM Online.

Berdasarkan hasil data karakteristik responden berdasarkan jenis kelamin, pengguna laki-laki sebesar 40 responden dan perempuan sebesar 20 responden. Dari data hasil yang didapatkan peneliti bisa menarik kesimpulan bahwa berdasarkan moderaotr jenis kelamin yang mempengaruhi ekspektasi kinerja terhadap minat pemanfaatan yang lebih dominan dalam menggunakan SIM Online yaitu jenis kelamin laki-laki. Hasil penelitian ini sejalan dengan penelitian [16] yang menyatakan bahwa moderatting gender dapat memoderasi hubungan ekspektasi kinerja terhadap minat pemanfaatan E-banking services dalam penelitian ini faktor yang lebih besar berpengaruh yaitu jenis kelamin laki-laki.

2. Variabel moderator jenis kelamin mempengaruhi ekspektasi usaha terhadap minat pemanfaatan

Variabel moderator jenis kelamin mempengaruhi ekspektasi usaha terhadap minat pemanfaatan mendapatkan hasil regresi pertama dan kedua mengalami peningkatan ditunjukkan pada Tabel 17 dan Tabel 18. Dikarenakan ada peningkatan antara variabel pertama dan kedua, artinya jenis kelamin memiliki efek moderasi yang memperkuat hubungan ekspektasi usaha terhadap minat pemanfaatan SIM Online. Penelitian ini sejalan dengan penelitian [16] yang menyatakan bahwa gender dapat memoderasi hubungan ekspektasi usaha terhadap minat pemanfaatan E-banking services.

3. Variabel moderator jenis kelamin mempengaruhi pengaruh sosial terhadap minat pemanfaatan

Variabel moderator jenis kelamin mempengaruhi pengaruh sosial terhadap minat pemanfaatan mendapatkan hasil regresi pertama dan kedua mengalami peningkatan ditunjukkan pada Tabel 19 dan Tabel 20 Dikarenakan ada peningkatan antara variabel pertama dan kedua, artinya jenis kelamin memiliki efek moderasi yang memperkuat hubungan pengaruh sosial terhadap minat pemanfaatan SIM Online. Penelitian ini sejalan dengan penelitian [17] menunjukkan bahwa gender hanya signifikan mempengaruhi facilitating conditions terhadap behavioral intention masyarakat Gondokusuman untuk menggunakan e-KTP.

\subsubsection{Pembahasan Moderator Umur}

1. Variabel moderator umur mempengaruhi variabel ekspektasi kinerja terhadap minat pemanfaatan

Variabel moderator umur mempengaruhi ekspektasi kinerja terhadap minat pemanfaatan mendapatkan hasil regresi pertama dan kedua tidak mengalami peningkatan ditunjukkan pada Tabel 21 dan Tabel 22. Dikarenakan tidak peningkatan antara variabel pertama dan kedua, artinya umur tidak memiliki efek moderasi yang memperkuat atau memperlemah hubungan ekspektasi kinerja terhadap minat pemanfaatan SIM Online.

Penelitian ini sejalan dengan penelitian [17] yang menunjukkan hasil penelitian bahwa tidak ada pengaruh efek moderasi umur yang memperkuat hubungan ekspektasi kinerja dengan penerimaan E-Ktp di Kecamatan Gondokusuman Yogyakarta. Penelitian ini tidak sejalan dengan penelitian [16] 
yang menyatakan bahwa age dapat memoderasi ekspektasi kinerja terhdapa minat pemanfaatan E-banking services.

2. Variabel moderator umur mempengaruhi ekspektasi usaha terhadap minat pemanfaatan

Variabel moderator umur mempengaruhi ekspektasi usaha terhadap minat pemanfaatan mendapatkan hasil regresi pertama dan kedua mengalami peningkatan ditunjukkan pada Tabel 23 dan Tabel 24. Dikarenakan ada peningkatan antara variabel pertama dan kedua, artinya umur memiliki efek moderasi yang memperkuat hubungan ekspektasi usaha terhadap minat pemanfaatan SIM Online.

Berdasarkan hasil data karakteristik responden berdasarkan umur, responden umur dari kisaran (17-25tahun) 17 responden kisaran umur (26-35 tahun) 41 responden dan kisaran umur (26-44 tahun) 7 responden. Dari data hasil yang didapatkan peneliti bisa menarik kesimpulan bahwa berdasarkan moderator umur yang mempengaruhi ekspektasi usaha terhadap minat pemanfaatan yang lebih dominan dalam menggunakan SIM Online yaitu kisaran umur 26 tahun- 35 tahun. Penelitian [11] yang menyatakan variabel moderator umur berpengaruh dalam penerimaan pengguna terhadap SAP (System Application and Product in data processing) dalam sistem ERP (Enterprise Resources Planning). Penelitan lainnya dari [18] umur memilki efek moderasi yang memperkuat hubugan ekspektasi usaha terhadap minat pemanfaatan New Operation Support System-Fulfillment

3. Variabel moderator umur mempengaruhi pengaruh sosial terhadap minat pemanfaatan

Variabel moderator umur mempengaruhi pengaruh sosial terhadap minat pemanfaatan mendapatkan hasil regresi pertama dan kedua mengalami peningkatan ditunjukkan pada Tabel 25 dan Tabel 26. Dikarenakan ada peningkatan antara variabel pertama dan kedua, artinya umur memiliki efek moderasi yang memperkuat hubungan pengaruh sosial terhadap minat pemanfaatan SIM Online. Sejalan dengan penelitian [16] age dapat memoderasi social influce terhadap minat pemanfaatan E-banking services. [11] faktor umur dapat memodari pengaruh sosial terhadap minat pemanfaatan, karna dapa memberikan pengaruh dalam penerimaan pengguna karena pengguna memerlukan pengaruh dari orang lain dan budaya perusahaan untuk menggunakan Enterprise Resources Planning.

4. Variabel moderator umur mempengaruhi kondisi yang memfasilitasi terhadap perilaku pengguna

Variabel moderator umur mempengaruhi kondisi yang memfasilitasi terhadap perilaku pengguna mendapatkan hasil regresi pertama dan kedua mengalami peningkatan ditunjukkan pada Tabel 27 dan Tabel 28. Dikarenakan ada peningkatan antara variabel pertama dan kedua, artinya umur memiliki efek moderasi yang memperkuat hubungan kondisi yang memfasilitasi terhadap perilaku pengguna SIM Online. [19] yang menyatakan bahwa kondisi fasilitas mempengaruhi perilaku penggunaan namun tidak memiliki pengaruh terhadap minat pemanfaatan melainkan memiliki pengaruh langsung terhadap perilaku penggunaan Sistem Informasi Perpustakaan Umum Kota Surabaya. Sejalan juga dengan penelitian [11] yang menyatakan variabel umur mempengaruhi facilitating condition karna memberikan pengaruh terhadap perilaku pengguna karena pengguna memerlukan fasilitas yang dapat mendukung.

\subsubsection{Pembahasan Moderator Pengalaman}

1. Variabel moderator pengalaman mempengaruhi ekspektasi usaha terhadap minat pemanfaatan

Variabel moderator pengalaman mempengaruhi ekspektasi usaha terhadap minat pemanfaatan mendapatkan hasil regresi pertama dan kedua mengalami peningkatan ditunjukkan pada Tabel 29 dan Tabel 30. Dikarenakan ada peningkatan antara variabel pertama dan kedua, artinya pengalaman memiliki efek moderasi yang memperkuat hubungan ekspektasi usaha terhadap minat pemanfaatan SIM Online. Berdasarkan hasil data karakteristik responden berdasarkan pengalaman rata-rata responden pengguna baru pertama kali menggunakan SIM Online. Hal ini sejalan dengan penelitian [7] yang menyatakan variabel Pengalaman sebagai moderasi dengan GSCA yang menunjukkan hasil positif dan signifikan dengan nilai critical rasio sebesar 3.09 dan koefisien jalur sebesar 0.200, sehingga dapat disimpulkan bahwa Ekspektasi Kinerja memiliki pengaruh yang signifikan dengan Minat Pemanfaatan. [11] yang menyatakan variabel moderator pengalaman berpengaruh dalam penerimaan pengguna terhadap System Application and Product in data processing dalam sistem Enterprise Resources Planning.

2. Variabel moderator pengalaman mempengaruhi pengaruh sosial terhadap minat pemanfaatan

Variabel moderator pengalaman mempengaruhi pengaruh sosial terhadap minat pemanfaatan mendapatkan hasil regresi pertama dan kedua mengalami peningkatan ditunjukkan pada Tabel 31 dan Tabel 32. Dikarenakan ada peningkatan antara variabel pertama dan kedua, artinya pengalaman memiliki efek moderasi yang memperkuat hubungan pengaruh sosial terhadap minat pemanfaatan SIM Online. Sejalan dengan penelitian [11] yang menyatakan bahwa faktor pengalaman memiliki efek moderasi yang memeperkuat hubungan pengaruh sosial terhadap perilaku pengguna karena faktor lamanya penggunaan ERP oleh pengguna memberikan pengaruh dalam minat pengguna terhadap sistem ERP. Sejalan dengan penelitian [7], [11] yang menyatakan semakin tinggi pengalaman yang di dapat semakin tinggi pula minat individu untuk menggunakan TI. Yang berarti pengalaman mempengaruhi pengaruh sosial terhadap minat pemnafaatan.

3. Variabel moderator pengalaman mempengaruhi kondisi yang memfasilitasi terhadap perilaku pengguna

Variabel moderator pengalaman mempengaruhi kondisi yang memfasilitasi terhadap perilaku pengguna mendapatkan 
hasil regresi pertama dan kedua mengalami peningkatan

peningkatan antara variabel pertama dan kedua, artinya pengalaman memiliki efek moderasi yang memperkuat hubungan kondisi yang memfasilitasi terhadap perilaku pengguna SIM Online. Penelitian ini sejalan dengan penelitian [7] yang menyatakan bahwa semakin tinggi pengalaman yang di semakin tinggi pula perilaku pengguna TI. Tidak sejalan dengan penelitian [18] yang menyatakan bahwa experience tidak memoderasi hubungan facilitating condition terhadap use behavior.

\section{KESIMPULAN DAN SARAN}

\subsection{KESIMPULAN}

Berdasarkan hasil analisis dan pemabahasan maka dapat disimpulkan penelitian ini sebagai berikut :

1.Ekspektasi kinerja berpengaruh positif terhadap minat pemanfaatan SIM Online. Pengguna percaya bahwa menggunakan SIM Online dapat meningkatkan kinerja pekerjaannya. Selain itu pengguna juga percaya bahwa menggunakan SIM Online dapat mengefisienkan waktu pembuatan atau perpanjangan SIM, dalam hal ini SIM Online dapat memberikan manfaat bagi pengguna untuk menyelesaikan proses pembuatan atau perpanjangan SIM lebih cepat.

2. Ekspektasi usaha berpengaruh positif terhadap minat pemanfaatan SIM Online. Pengguna percaya bahwa menggunakan SIM Online tidak membutuhkan waktu yang lama dalam proses pembuatan atau perpanjangan SIM. Selain itu pengguna juga percaya bahwa fitur yang ada pada SIM Online mudah untuk dipahami.

3. Pengaruh sosial berpengaruh positif terhadap minat pemanfaatan SIM Online. Pengguna percaya bahwa menggunakan SIM Online membuat pengguna merasa update dalam proses pembuatan atau perpanjangan SIM.

4. Faktor kondisi yang memfasilitasi berpengaruh positif terhadap perilaku pengguna SIM Online. Bahwa fasilitas yang pengguna punya sangat mendukung dalam menggunakan SIM Online.

5. Minat pemanfaatan berpengaruh positif terhadap perilaku pengguna SIM Online. Pengguna mempunyai keinginan menggunakan SIM Online untuk waktu yang akan datang.

6. Variabel moderator jenis kelamin memperkuat hubungan variabel ekspektasi kinerja terhadap minat pemanfaatan SIM Online.

7. Variabel moderator jenis kelamin memperkuat hubungan ekspektasi usaha terhadap minat pemanfaatan SIM Online.

8. Variabel moderator jenis kelamin memperkuat hubungan pengaruh sosial terhadap minat pemanfaatan SIM Online.

9. Variabel umur memiliki efek moderasi yang tidak memperkuat atau memperlemah hubungan ekspektasi kinerja terhadap minat pemanfaatan SIM Online . ditunjukkan pada Tabel 33 dan Tabel 34. Dikarenakan ada

10. Variabel moderator umur memperkuat hubungan ekspektasi usaha terhadap minat pemanfaaatan SIM Online.

11. Variabel moderator umur memperkuat hubungan antara pengaruh sosial terhadap minat pemanfaatan SIM Online.

12. Variabel moderator pengalaman memperkuat hubungan pengaruh sosial terhadap minat pemanfaatan SIM Online.

13. Variabel moderator pengalaman memperkuat hubungan antara ekspektasi usaha terhadap minat pemanfaatan SIM Online.

14. Variabel moderator umur memperkuat hubungan kondisi yang memfasilitasi dengan perilaku pengguna SIM Online.

15. Variabel moderator pengalaman memperkuat hubungan kondisi yang memfasilitasi dengan perilaku pengguna SIM Online.

\subsection{SARAN}

Berdasarkan hasil penelitian hanya satu hipotesis yang tidak diterima berarti secara keseluruhan bahwa SIM Online ini dapat di terima oleh pengguna. Oleh karna itu, lingkup penelitian dapat diperluas sesuai dengan sasaran SIM Online yang dapat digunakan oleh semua orang.

\section{REFERENCES}

[1] D. . Pradopo, Undang undang kepolisian Nomor 10 Tahun 2012 Tentang Pengaturan Lalu Lintas Dalam Keadaan Tertentu Dan Penggunaan Jalan SelainUntuk Kegiatan Lalu Lintas. Jakarta, 2012.

[2] V. Venkatesh, M. G. Morris, G. B. Davis, and F. D. Davis, "User Acceptance of Information Technology: Toward a Unified View Author ( $\mathrm{s}$ ): Viswanath Venkatesh, Michael G . Morris, Gordon B . Davis, Fred D . Davis Published by: Management Information Systems Research Center, University of Minnesota," vol. 27, no. 3, pp. 425-478, 2003.

[3] W. . W. B Raharjo, Nugroho, "Analisis faktor determinan penggunaan sistem informasi sumber daya manusia dan implikasinya terhadap reformasi birokrasi pada bpk ri," J. Inform., vol. 10, no. 1, pp. 1149-1155, 2016.

[4] D. Sugiyono, Metode Penelitian Dan Pengembangan Research and Development, II. Bandung: Alfabeta, 2016.

[5] S. Siregar, Statistik Parametik untuk Penelitian Kuantitatif. Jakarta: PT Bumi Aksara, 2015.

[6] I. Ghozali, Aplikasi Analisis Multivariate dengan Program, VII. Semarang: Badan Penerbit Universitas Diponegoro, 2013.

[7] W. Bharata and W. Widyaningrum, "Analisis penerimaan dan penggunaan sistem informasi akademik melalui pengembangan model UTAUT," 
jurnal.unismabekasi.ac.id, vol. 11, no. 2, pp. 171-187, 2017.

[8] G. Baptista and T. Oliviera, "Understanding mobile banking: The unified theory of acceptance and use of technology combined with cultural moderators," 2015.

[9] Ismarmiaty, "Analisis Pengaruh ariabel Model UTAUT Terhadap Penerimaan Dan Penggunaan Aplikasi Badan Penyelenggara Jaminan Sosial," J. Manaj. dan Tek. Ind. Produksi, vol. 17, no. 1, 2017.

[10] I. W. Kusumawardani, E. D. Wahyuni, and W. Suharso, "Analisis Penerimaan dan Penggunaan Aplikasi Work Order Android Menggunakan Metode UTAUT Pada PDAM Kota Malang," Comput. Inf. Technol., vol. 1, no. 2, pp. 82-89, 2018.

[11] Y. W. Handayani, "Analisis faktor-faktor yang mempengaruhi penerimaan pengguna dalam menggunakan sistem ERP dengan studi kasus PT XYZ," Sist. Inf., vol. 7, pp. 69-75, 2011.

[12] R. N. Mustaqim, A. Kusyanti, and H. Aryadita, "Analisis Faktor-Faktor yang Memengaruhi Niat Penggunaan E-Commerce XYZ Menggunakan Model UTAUT ( Unified Theory Acceptance and Use Of Technology )," J. Pengemb. Teknol. Infromasi dan Ilmu Komput., vol. 2, no. 7, pp. 2584-2593, 2018.

[13] E. Silviasasmi, "Pembelajaran terbuka Indonesia (GARSUPATI) menggunakan model Unified Theory of acceptance and use of technology (UTAUT)," Jurusan Pendidikan Teknik Informatika Universitas Pendidikan Ganesha. Singaraja, 2018.

[14] S. Nugraha and K. Yadnya, "Penerapan Model Utaut Dalam Menjelaskan Faktor Minat Dan Penggunaan Sistem Informasi Manajemen Daerah," J. Akunt. Univ. Udayana, vol. 24, no. 56, pp. 959-987, 2018.

[15] Y. Malau, "Penggunaan Aplikasi Transportasi Online
(Studi Kasus: Wilayah JABODETABEK),” pp. 69-74, 2016.

[16] K. Ghalandari, "The Effect of Performance Expectancy , Effort Expectancy, Social Influence and Facilitating Conditions on Acceptance of E-Banking Services in Iran: the Moderating Role of Age and Gender," vol. 12, no. 6, pp. 801-807, 2012.

[17] M. Indriani, "Efek Moderasi Dari Usia Dan Jenis Kelamin Dalam Penerimaan E-KTP Di Kecamatan Gondokusuman Yogyakarta," vol. 14, no. 1, pp. 4362, 2012.

[18] R. Yunis, A. Tiana, and F. Astuti, "Analisis Penerimaan Pengguna Akhir dengan Model UTAUT : Peran Gender , Age , dan Experience dalam Menggunakan NOSS-F Systems," pp. 189-194, 2017.

[19] D. B. Syafutri, "Analisis Sistem Informasi Perpustakaan (Sipus) MenggunakanModel Unified Theory Of Acceptance And Use Of Technology(Utaut) Di Perpustakaan Umum Kota Surabaya," J. Airlangga Univ., vol. 10, no. 2, pp. 1-9, 2017. 